\title{
Miranda
}

Revue pluridisciplinaire du monde anglophone /

Multidisciplinary peer-reviewed journal on the English-

speaking world

19 | 2019

Rethinking Laughter in Contemporary Anglophone Theatre

\section{Roy McFarlane. The Healing Next Time.}

\section{Eric Doumerc}

\section{OpenEdition}

\section{Journals}

Electronic version

URL: http://journals.openedition.org/miranda/21538

DOI: 10.4000/miranda.21538

ISSN: 2108-6559

\section{Publisher}

Université Toulouse - Jean Jaurès

Printed version

Date of publication: 7 October 2019

\section{Electronic reference}

Eric Doumerc, "Roy McFarlane. The Healing Next Time.", Miranda [Online], 19 | 2019, Online since 14

October 2019, connection on 16 February 2021. URL: http://journals.openedition.org/miranda/21538 ; DOI: https://doi.org/10.4000/miranda.21538

\section{This text was automatically generated on 16 February 2021.}

\section{(@) $\odot \Theta$}

Miranda is licensed under a Creative Commons Attribution-NonCommercial-NoDerivatives 4.0 International License. 


\title{
Roy McFarlane. The Healing Next
}

\section{Time.}

\author{
Eric Doumerc
}

\section{REFERENCES}

Roy McFarlane. The Healing Next Time (Rugby: Nine Arches Press, 2018), 79 p, ISBN: 9781911027454

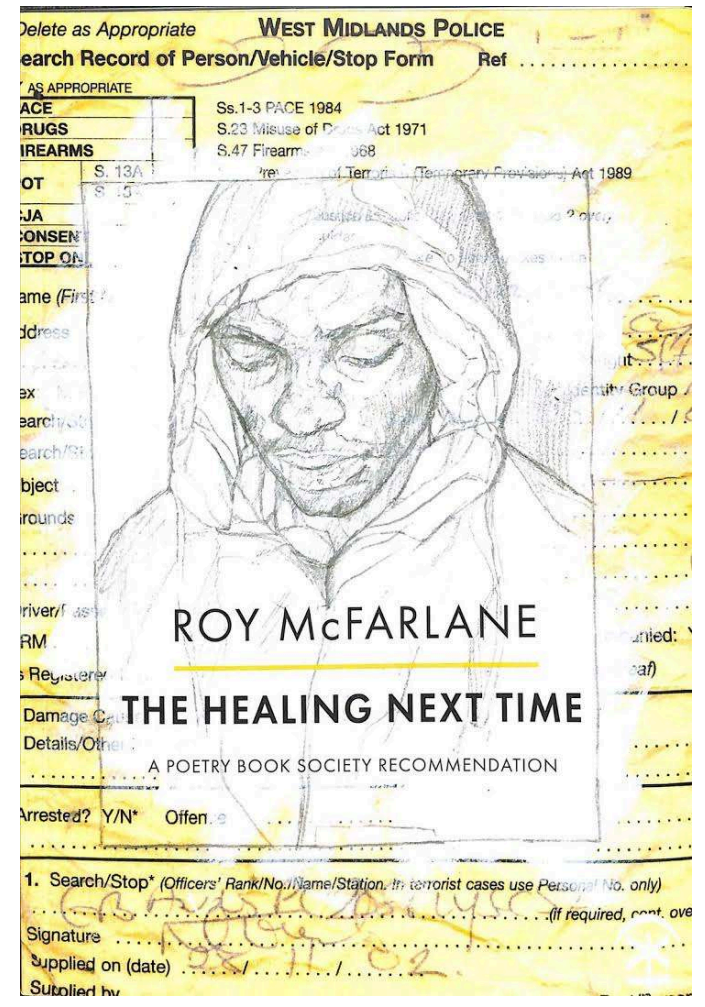


1 Roy McFarlane is a British poet of Jamaican parentage who was born in Birmingham and has lived most of his life in Wolverhampton, in the West Midlands. In 2009 he was appointed Starbucks' Poet in Residence and in 2010-2011, he was Birmingham's Poet Laureate. Over the years his poems have appeared in various magazines and anthologies like Out of Bounds (Bloodaxe Books, 2012) and Filigree (Peepal Tree, 2018). His first collection of poems, Beginning With Your Last Breath, was published by Nine Arches Press in 2016.

2 The Healing Next Time is his second collection and was published in October 2018. It continues the strong autobiographical strand which was present in Beginning With Your Last Breath and can be seen as an examination of what it means to have grown up black in Britain. The title of the collection is a reference to James Baldwin's The Fire Next Time, which was itself based on a quotation from the Bible: after the Flood, a rainbow appeared in the sky, which implied that the next time, God's wrath would take the form of fire instead of water.

3 The collection falls into three sections which constitute a kind of progression from racial division, racial oppression, to the need for forgiveness and healing.

The first section, entitled "New Millennium Journal" covers the period from 1999 to 2006 which can be seen as being dominated by the Stephen Lawrence Inquiry and by the setting up of anti-racist police in its wake. Stephen Lawrence was a black teenager who was murdered by five white boys in 1993. The white thugs were arrested, but they were released due to insufficient evidence to convict them. It was later revealed that the police had overlooked crucial evidence that could have led to the conviction of the killers. The young boy's parents campaigned for an investigation into the behaviour of the police and into its handling of the case. John Major's government refused to allow the investigation, but when Tony Blair became Prime Minister he allowed the investigation to proceed.

5 The McPherson Report was finally published in the first week of March 1999 and caused quite a stir in Britain. The report accused the Metropolitan Police Force of being institutionally racist and advocated a number of reforms to improve race relations in Britain, like the extension of the coverage of the Race Relations Acts to the police force and public services including the civil service and the National Health Service. The Report also proposed a new definition of racism which would include unwitting prejudice and racist stereotyping.

6 This first section mixes the personal with the political, with the persona's life being in turmoil during these difficult years when he was employed as a Mental Health Community Development Worker to set up anti-racist police. After seven years, funding was withdrawn, and anti-racism was no longer deemed a priority:

A manager thanks him for all the work he's done, but funds are coming

to an end. You kidding me, seven years and they're closing us down.

Seven years to rewrite centuries of hate. Seven years to plant seeds of hope.

Always waiting for riots, or a Stephen Lawrence, don't they ever learn?

A table is turned upside down. (34)

7 The second section, entitled "... they killed them", is based on the poet's research at the Institute of Race Relations' Archives and consists in a series of eighteen experimental sonnets which tackle the sensitive issue of the death of people from ethnic minorities in police custody. Each sonnet is devoted to a landmark case, from David Oluwale (1969) to Rashan Charles (2017). 
The epigraph to the second section comes Claudia Rankine's Citizen: An American Lyric: "Won't you write about Duggan? The man wants to know". Mark Duggan was a young person of Afro-Caribbean parentage who was shot by the police in 2011, which led to the summer riots of 2011. A controversial figure (he was known for his association with the criminal underworld on Broadwater Farm Estate), his shooting led to contradictory statements, which is rendered in the sonnet devoted to him by a dual structure. The shape of the poem itself brings to mind an angel, which refers to the poem's epigraph, a quote by a community activist: "He wasn't an angel, but if you're brought up in a place like the Broadwater Farm estate, you better not be an angel because you won't survive" (54). This poem is an example of shaped or concrete poetry and is weirdly reminiscent of the Metaphysical poet George Herbert's "Easter Wings".

9 The third section, entitled "Gospel According to Rasta", looks at the healing process and the figure of the Rastaman appears in several pieces, symbolising ancestral wisdom and a certain take on life. The healing process can be facilitated by ancestral culture, as is implied in "Dancing With Ghosts", but also by a willingness to embrace all cultures and traditions, as in the poem entitled "Gabay of Hope," after the Somali long poem form of the same name: "Let our bodies/be a Hajj, until we become the Hannukah of the night and the Halcyon of days" (72).

This second collection finds Roy McFarlane willing to experiment with various poetic forms (like the gabay, a Somali long poem, or shaped poetry) and ready to tackle sensitive issues like the death of people from ethnic minorities in custody. As in his first collection, a great formal elegance and a tough determination to tell his own story are constantly present and make his work immensely accessible.

\section{INDEX}

Mots-clés: poésie anglo-antillaise

Keywords: Black British poetry

\section{AUTHORS}

\section{ERIC DOUMERC}

Maître de Conférences

Université de Toulouse - Jean Jaurès

eric.doumerc@univ-tlse2.fr 